\title{
Carthusian symbolism in Architecture and Art: San Lorenzo of Padula
}

\author{
Maria Fernanda García Marino ${ }^{1}$ \\ ${ }^{1}$ Department of Architecture and Industrial Design - Università degli Studi della Campania "Luigi Vanvitelli" \\ Aversa (CE), Italy \\ Email: mariafernanda.garciamarino@unicampania.it
}

\begin{abstract}
The aim of this contribution is to demonstrate through the study of the concrete example of the Charterhouse di San Lorenzo in Padula (Province of Salerno, Italy) how and to what extent, the utopian value of the spirituality of the Carthusian monks - inspired by the model of the Desert Fathers and the Church of primitive Christianity, devoted to the practices of strict enclosure, of rigorous abstinence, of meditation, of contemplation and of prayer - has affected the definition and development of a specific iconography; both for what concerns the figurative arts, which have as a milestone the theme of martyrdom and angels (the creatures closest to God), present within the monasteries of the order, both for what interests the architectural structure of buildings. Always the same as themselves, especially for the design, distribution and function of the spaces, which as a whole and in particular, they reflect, strictly and everywhere, the immutability of the Carthusian Rule, never changed since the foundation of the order in 1084. Following the model of the first monastery, built on the Chartreuse massif, in Grenoble (France), made by St. Bruno of Cologne, new settlements were erected and spread throughout Europe, with an exponential growth that does not suffer interruptions until the end of eighteenth century and that, left a deep and unequivocal cultural mark in the territory on which they extended. The Charterhouse model, a kind of Earthly Jerusalem like an imitation of the Celestial Jerusalem, can be well included in the universe of utopian architecture, but of the possible ones, where spirituality became tangible reality and where the sacredness of space conceived and built by the monks puts us in touch today the man with sensitive and perceptible experience, the so-called hierophany.
\end{abstract}

(C) 2019 The Authors. Published by IEREK press. This is an open access article under the CC BY license (https://creativecommons.org/licenses/by/4.0/).

\section{Keywords}

Iconography; Art; symbolism; Architecture; Charterhouse; utopian; Religious Order.

\section{Preliminary issues. Saint Bruno and the foundation of the Carthusian Order}

It would be impossible to give an account of the value of the architectural and artistic heritage of the Charterhouses without fully understanding the personality of San Bruno founder of the Order, born in Cologne in Germany, endowed with profound theological knowledge and in relation to the flower of intellighentia and ecclesiastical power. Before retiring in 1084 on the Chartreuse massif near Grenoble (hence the name of the Order) and erecting, at over a thousand meters high, a hermitage that had the connotation of the Mother House (the Grande Chartreuse), the founder had he attended the School of High Theological Studies of Reims of which he soon became rector. This and other assignments he had obtained due to his profound theological preparation, were taken away from him by the new archbishop of Reims, Manasse. Once rehabilitated, refused the office of archbishop, choosing instead the eremitical 
life together with six of his followers (Landuino di Toscana, Stefano di Die, Stefano de Bourg, Ugo "the chaplain", Andrea and Guarino). This was the original nucleus of the new Order. After only six years, in 1090, the founder left the Mother House summoned to Rome by Pope Urban II de Châtillon. We are talking about a period in which the eternal city was besieged by the Imperial troops and by those of the antipope Clement III. So together with Urban II he was forced to move away from Rome and to wander, under the protection of the powerful Norman princes, throughout the South of Italy. Rejected yet another appointment as archbishop of Reggio Calabria, and obtained from the pope the permission to retire again to a hermit life, founded in 1091 a new Charterhouse, that of Serra San Bruno, in the Diocese of Squillace, where he remained until his death on 6 October 1101. If Bruno was the founder of the Order, he who consolidated it was Guigo I, the third prior of Chartreuse, who succeeded Landuino in 1109. With him began the slow and unstoppable expansion of the Carthusians and a true rule was drawn up (Consuetudines Cartusiae written between 1121 and 1127/28), the text was approved by Pope Innocent II on 22 December 1113. In 1270 the Consuetudines, with the addition of the Decrees of the General Chapters, took the name of Antiqua Statuta.

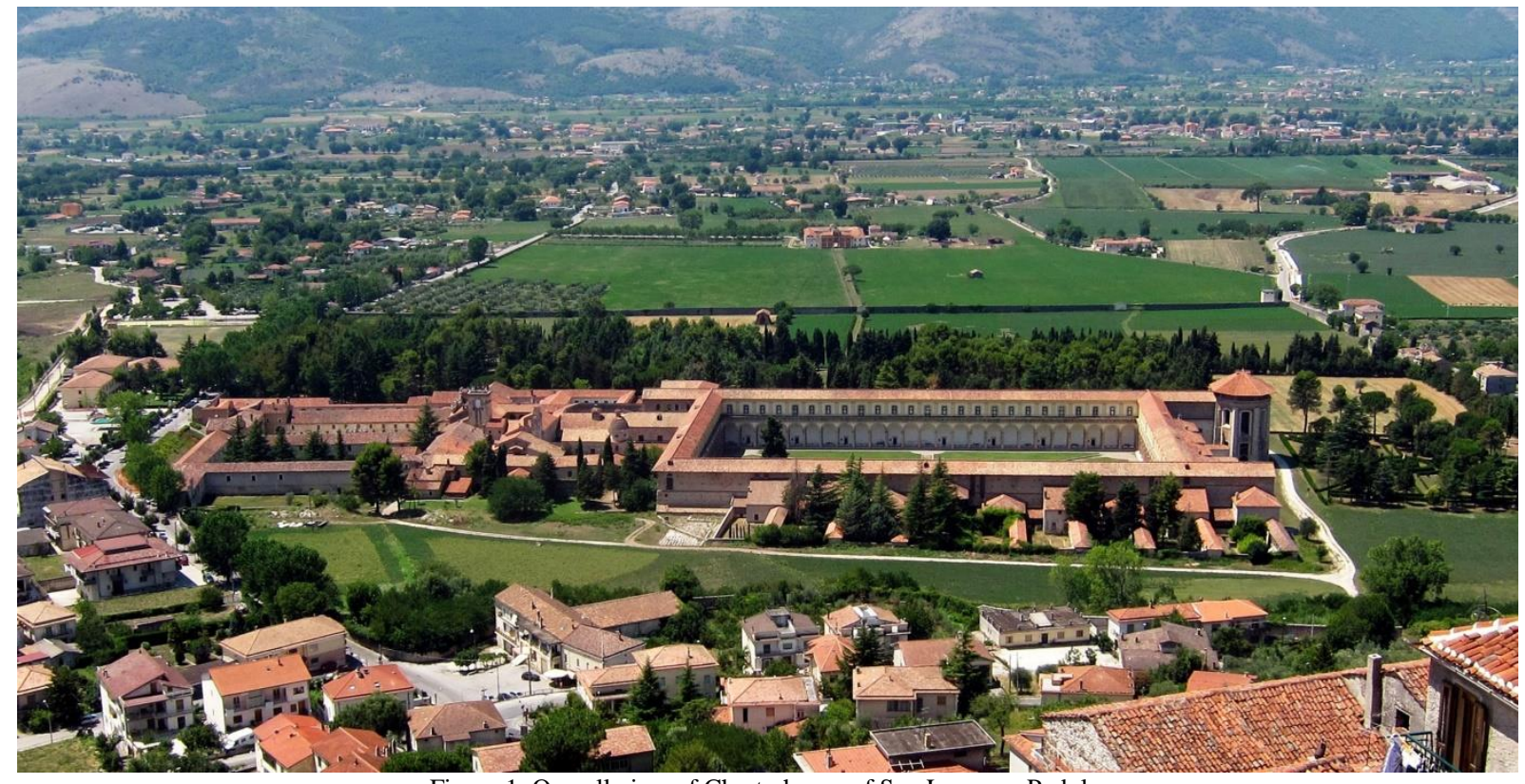

Figure 1. Overall view of Charterhouse of San Lorenzo, Padula.

\subsection{The Rule transformed into architecture.}

The Rule codified by Guigo, never essentially changed until today, is inspired by the Christianity of the origins, to that of the Fathers of the Desert, based on isolation, meditation, prayer and contemplation, the structure of the order included for two distinct categories of monks, the Fathers voted in strict enclosure, and the 'Conversi' (lay brothers) with the possibility of outward relations in order to allow the Fathers to live in perfect isolation. For this reason all the Carthusian monasteries in Europe have the same iconographic layout, the clear division between the Lower House - with the external courts and services, the kingdom of the 'Conversi'- and High House, where the life of the Fathers take place, this is divided into a coenobitic area and an eremitical zone (fig.1). Except in very rare cases (Pavia, Naples) the church is set in two zones, or two choirs, one for the Fathers (fig.2) and one for the 'Conversi'. All the "High houses" of the Carthusian complex have a large cloister where the cells of the Fathers are grafted in the shape of a comb, and where there is always the presence of the monks' cemetery (Hillman, 2004).

\subsection{The relationship of the Carthusians with art.}

It's essential to specify that in the Carthusian world the relationship with art is sustained in the relationship with God, and it takes place in two different moments, in the context of the High House; wich as already mentioned, is divided into a coenobitic and eremitical zone. In the first, consisting mainly of Church (fig.3), Treasury, Chapter Hall, Refectory, Kitchens, the Noble Guestroom with its cloister, the Fourth of Procurators, the Library and the Quarter of Prior, all those rooms are richly decorated, with stuccoes, sculptures, frescoes and paintings, the relationship with God is mediated through art and therefore with the beauty that have the function of stimulating the imagination and, 
consequently, the spirit. Basically the aim is to take the first step of the spiritual path and of metamorphosis from the physical to the metaphysical dimension that every Carthusian monk is bound to follow. As Guigo II, general order of the Order at the end of the 12th century, states in his Letter on the contemplative life, the Scala Claustralium consists of four steps: lectio, meditatio, oratio and contemplatio (De Martini, 1992). In the Great Cloister (for the monks, desert and paradise at the same time) the Carthusians who have already passed the first three degrees of the Scala Claustralium, come to a stage of pure contemplation where the approach with God is direct, not mediated. In this space and in the cells that are grafted onto it, everything is extremely geometric, meager, composed. The ornamentation that before was overwhelming disappears completely, the monks grant themselves only the presence of an image, a representation of the Madonna painted on the wall of the first room at the entrance of their cells, called Ave Maria. They no longer need mediation and art to approach sacredness, the relationship is now direct. The very rich figurative furniture in the spaces dedicated to the cenobitic life is reduced to a minimum in the hermitage, The very rich figurative furniture in the spaces dedicated to cenobitic life is reduced to a minimum in the hermitage, but gaining from the point of view of conceptual intensity and spiritual significance. "The ephemeral abandonments" of the cenobitic area give way to the "composite composure" of the eremitical zone (Calvino, 1972; De Cunzo, Giusti e De Martini, 1990). This is all the solution to the problem of the relationship of the Carthusians with art, often minimized or poorly understood.

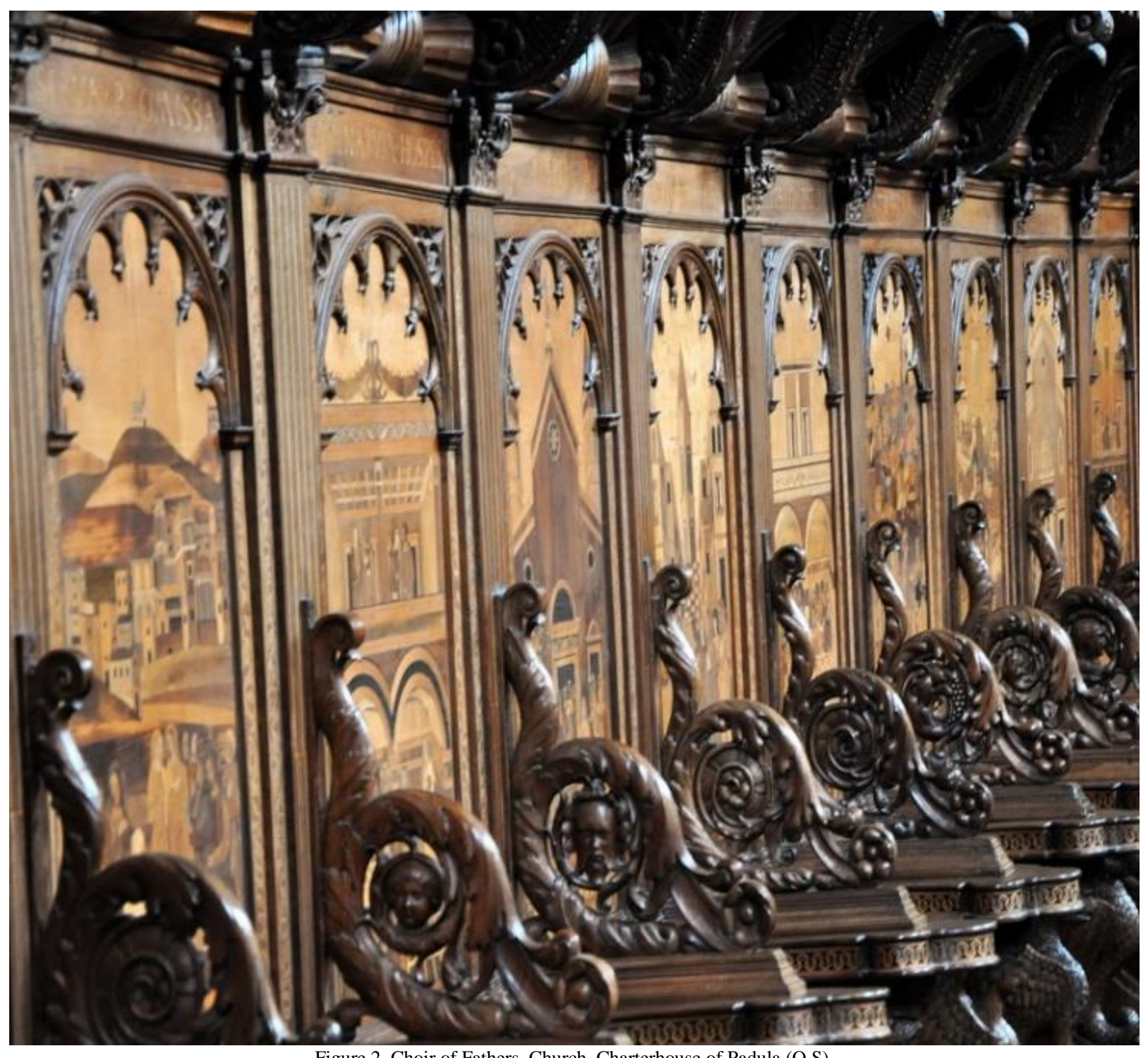

Figure 2. Choir of Fathers. Church. Charterhouse of Padula (O.S) 


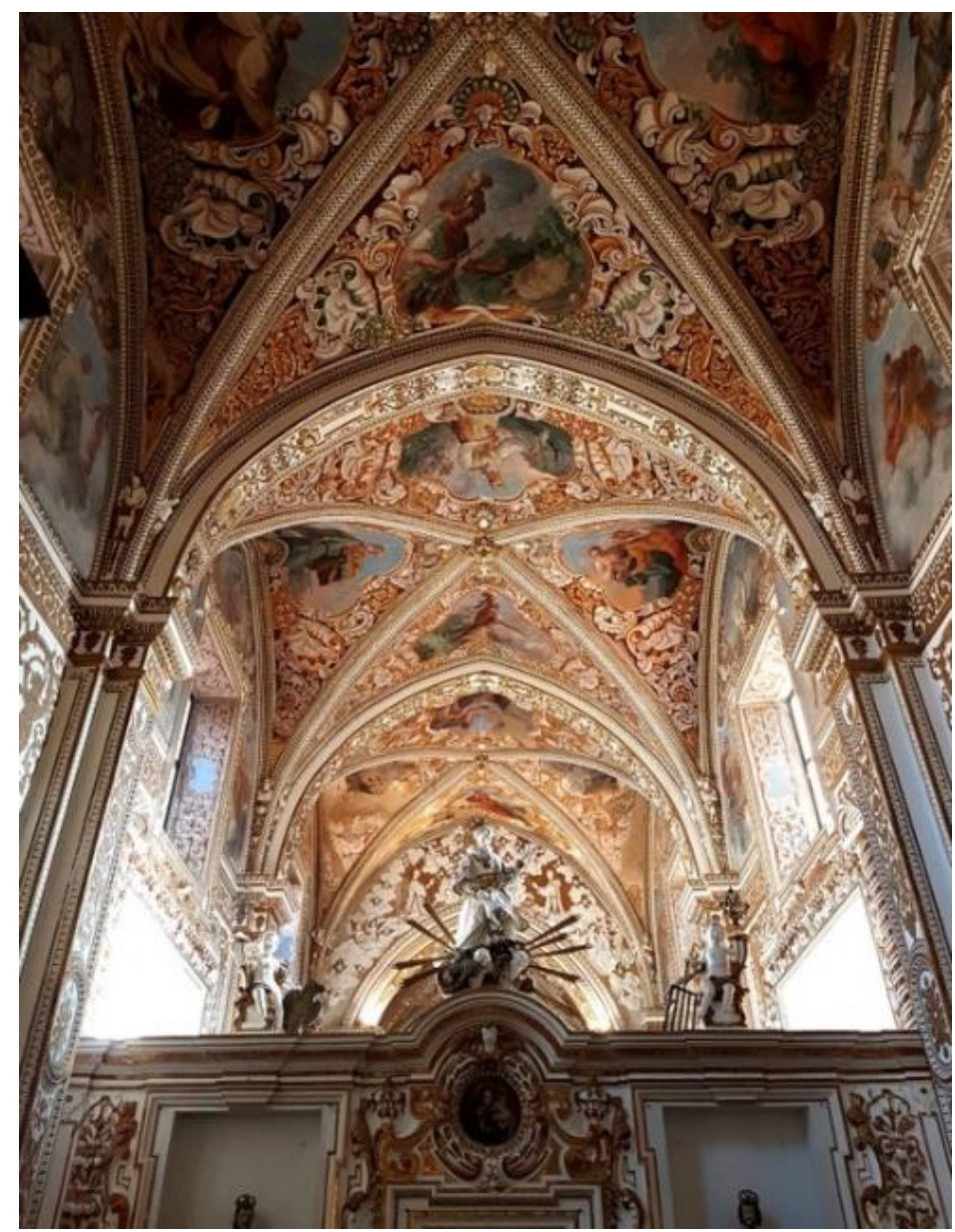

Figure 3. Presbytery. Charterhouse of Padula.

As Giovanni Leoncini says «The Carthusians have never refused to deal with the world [...] they have never shied away from contact with vanity and the reality of the century, testifying however that the true values were not there. It is indeed a spirituality through antithesis» (Leoncini, 1989). Therefore art is commissioned and pursued with conviction (never has a monastic order been so self-represented) certainly not because of the will of some enterprising prior but by virtue of an anagogic approach to Beauty, which is more widespread in religious culture than in the first monastic communities and until the middle ages (Eco, 1980).

culture than in the first monastic communities and until the middle ages (Eco, 1980).

\section{The Carthusian model. San Lorenzo di Padula.}

Founded between 1305 and 1306 on the Vallo di Diano plateau (territory on the border between Campania and Basilicata), by Tommaso Sanseverino, one of the most important feudal lords of the Angevin kingdom, dedicated to San Lorenzo martyr, is a paradigmatic example of this distributional structure. Despite its troubled history and the notable depletion of its most important artistic heritage, its iconographic value and its symbolic scheme have remained almost intact, such as to make it clear even today the ways of life and the rule of the Carthusian Order. The spiritual itinerary of the Carthusian monks from the physical to the metaphysical, from the immanent to the transcendent, from the earth to the sky is clearly visible through the sequence of its architectural spaces, a heavenly city, from the coenobitic environments, often of princely splendor to those of hermitic specimens simplicity (De Cunzo - De Martini, 1985). In Padula it's possible to retrace many of the specific iconographic themes that can be traced back to the Carthusian spirituality: the Martyrdom (Large Cloister), the contemplation of the Passion of Christ ("Ex Sala del Capitolo delle Colpe") and the Angels (Ciborium). Concerning the first theme, in the great Cloister, the heart of the Charterhouse, a stone frieze with triglyphs and metopes, built between the XVII and XVIII, takes place along all four sides of the arcade, above the arches (Bachelard, 2006). (fig.4-5). Immages of the Carthusians martyred in England between 1535 and 1541 under the reign of Henry VIII, the Carthusian founders, the evangelists and the apostles follow one another in high relief. In continuation the symbols of the Passion of Christ and a sequence of holy hermits. 
The message is clear, the physical and spiritual martyrdom that rightly takes place in the space of the desert-paradise Cloister. The Martyrdom is intended as a sort of Imitatio Christi, closely related to the theme of contemplation of the Passion of Christ and its symbols. In Padula, in the seventeenth-century fresco of the back wall of the Ancient Chapter of the Faults (in the '700 transformed into a Kitchen) to watch over the body of Christ barely disengaged from the Cross, the Carthusian monks appear white. In other depictions present in the European Carthusian monasteries the adoring ones are angels (an example of this is The dead Christ watched over by the angels by Reynaud Levieux, dated around 1651, from the Charterhouse of Villeneuve-Lès-Avignon). The angelic iconographic repertoire and that of the Carthusian monks are therefore interchangeable. Concept taken from the patristic tradition and in particular by the Angelology of Origen (185-254 C). According to this theory rational creatures are divided into three categories: angels, demons or men, who are in turn interchangeable on the basis of their free will. As it is easy to understand, angel and demon are the faces of the same coin. Thus the equilibrium of the Carthusian fathers, men-angels (by their own admission declared, from the Epistola ad fratres de Monte Dei, attributed to Guido I) is continually threatened. It is no coincidence that the theme of temptation is one of the most present in Carthusian iconography. The most serious sin is that of pride, often expressed in the depiction of the theme of the fall of the Rebel Angels.

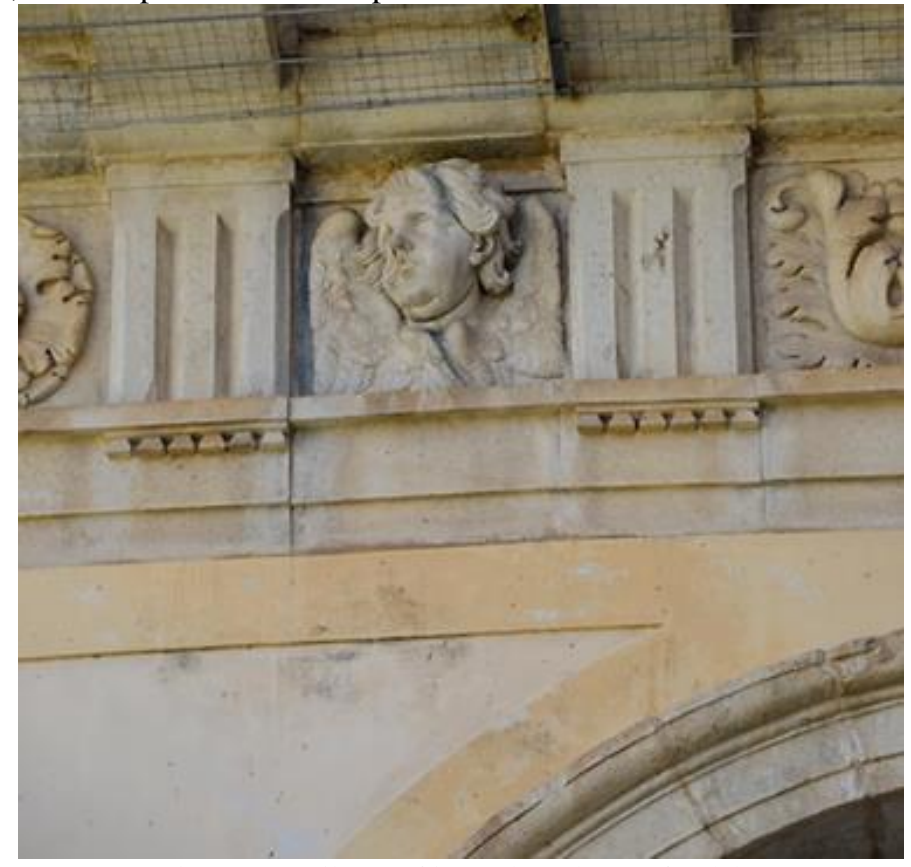

Figure 4. Detail.Stone frieze. Charterhouse of Padula.

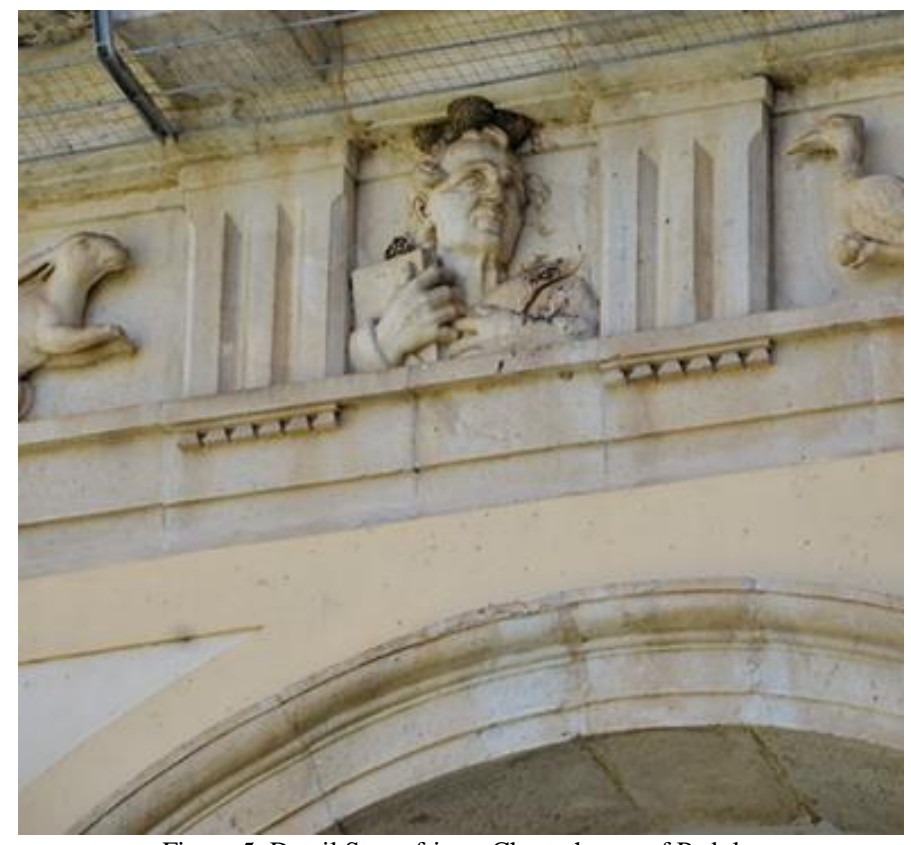

Figure 5. Detail.Stone frieze. Charterhouse of Padula. 


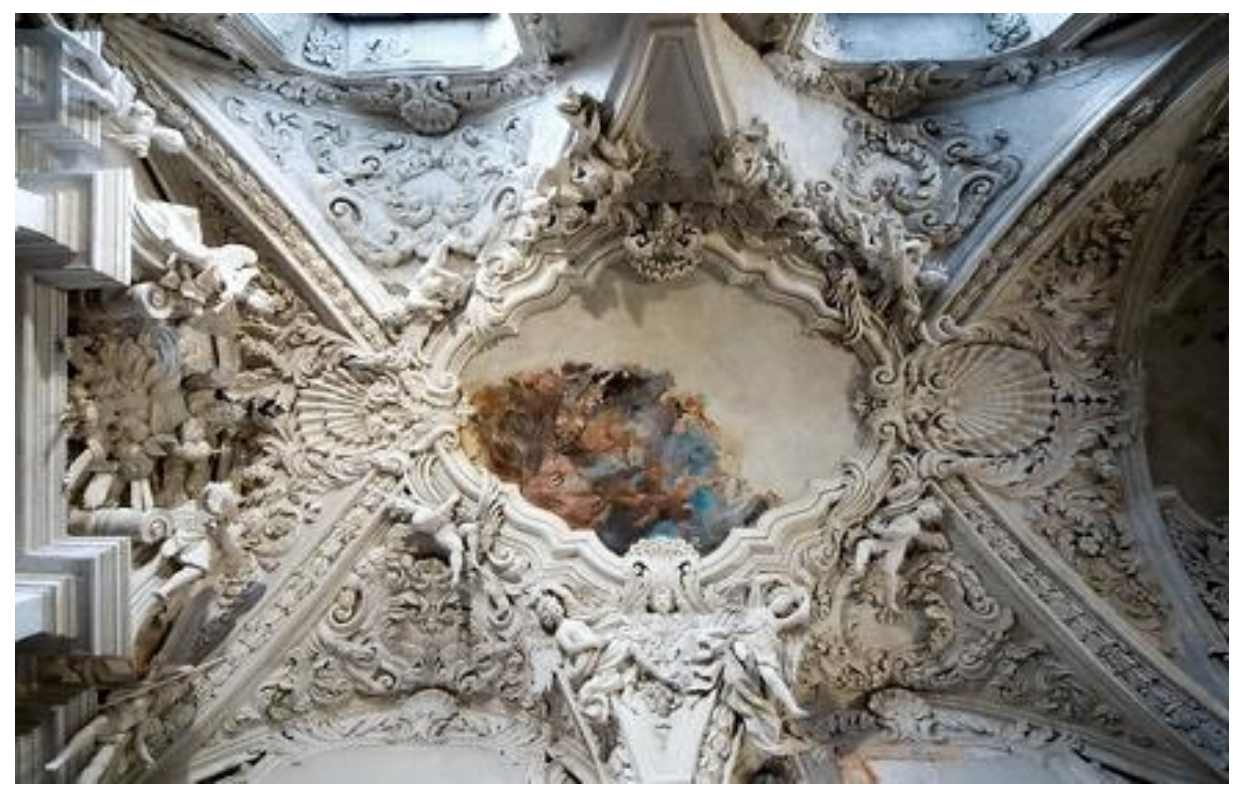

Figure 6. Vault. Chapel of the Treasure. Charterhouse of Padula (O.S).

In Padula the vault of the Chapel of the Treasure decorated with a fresco in the center depicting Saint Michael the Archangel who fights and drives away the angels now transformed into demons (fig.6). Around the painted scene, stucco demons take shape, and are in freefall. It is not surprising that the references to humility abound in the inscriptions of choirs within the Church of San Lorenzo, as well as images relating to scenes of temptations (for example Sant'Antonio, San Macario, etc.) and demonic figures. Finally, the bronze Ciborium of San Lorenzo, made by Jacopo del Duca between 1588 and 1590, is emblematic of Carthusian spirituality and iconography. The eight scenes of the central body of the artefact (Last Supper, Garden of Olives, Flagellation, Jesus at Calvary, Crucifixion, Deposition from the Cross, Pietà and Resurrection) make explicit the practice of meditation and adoration of the Body of Christ. Simultaneously with the scenes of the Passion the Ciborium was full of angelic representations. Originally on the base of the small dome eight angels rose in the round with the symbols of the Passion in their hands. These presences are however dominant in the entire artifact as it has been until today. It is also interesting to note that traces of the ancient painting (gold, red, blue) are visible (fig.7-8).

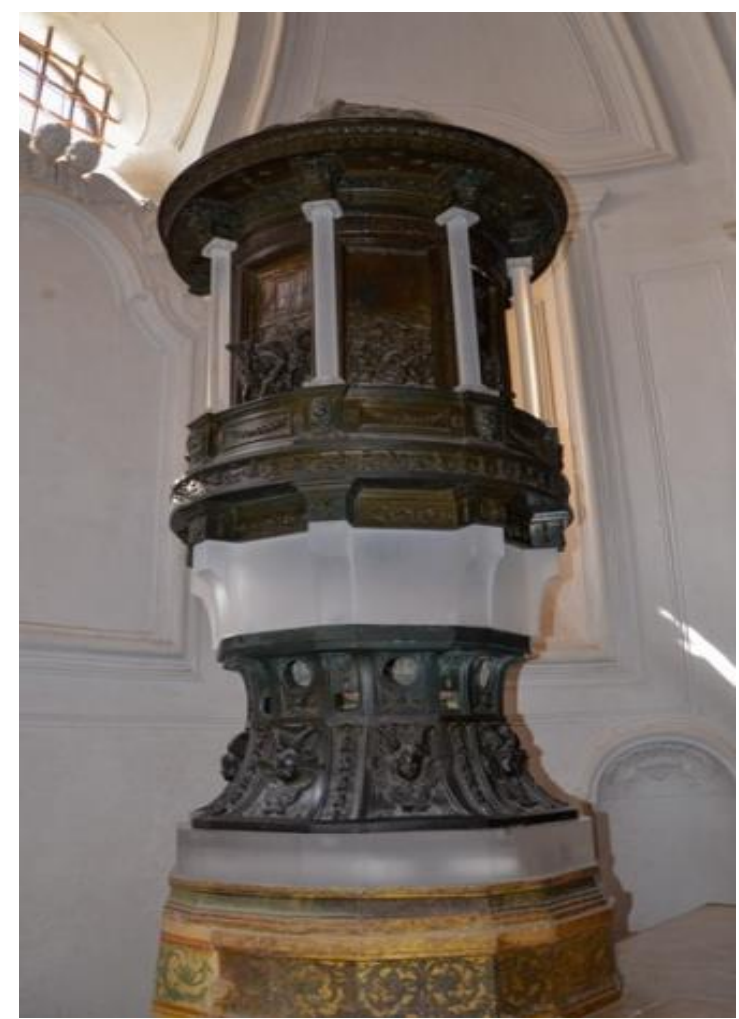

Figure 7. Ciborium. Sacristy.Charterhouse of Padula (O.S). 


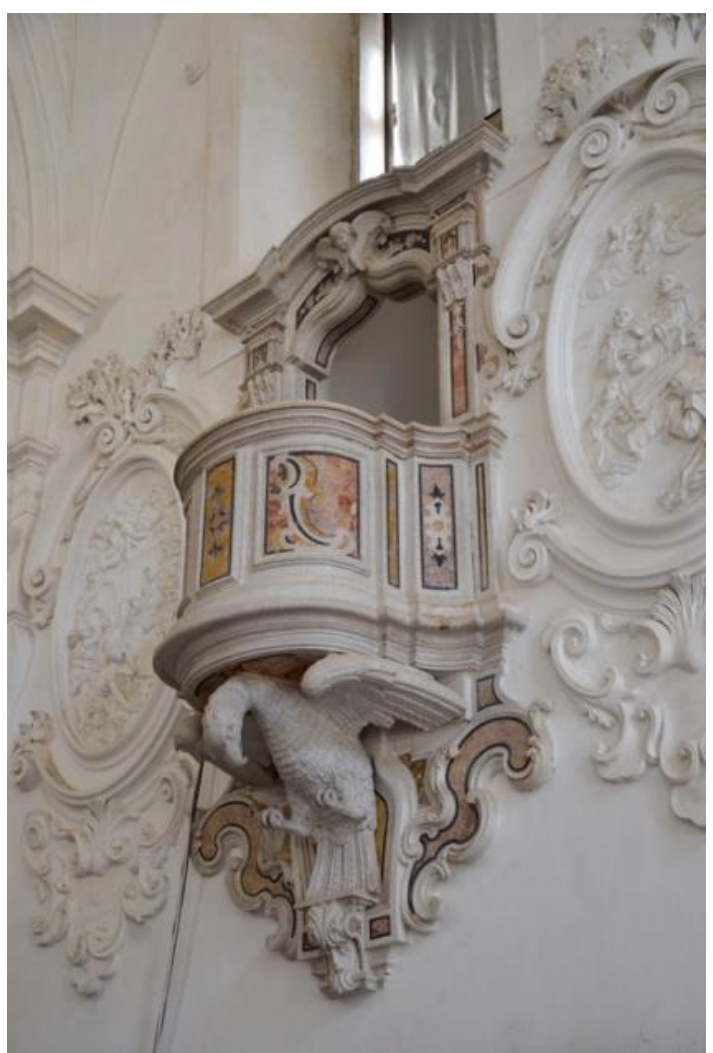

Figure 8. Pulpit. Refectory. Charterhouse of Padula (O.S).

\section{Conclusions}

All the Carthusian monasteries found in Italian territory, as well as those of the rest of Europe, have an identical architectural layout, characterized by a specific function and the same distribution of spaces, based on the rigidity of the Carthusian rule. This is an interesting peculiarity that is testified by the Gallerie des Cartes, a series of bird's-eye paintings of the European Carthusian monasteries between the late 17th and early 18th centuries, commissioned by the prior general of the order Le Masson and now preserved in the Charterhouse of Grenoble. Another important topic, heavily debated, is that of the relationship of the Carthusians with art. At first glance it is difficult to understand how an order of extreme enclosure, based on the spirituality of the origins of Christianity and of the fathers of the desert, has so much frequentation with art. It was Ludolfo di Sassonia, one of the most eminent theorists of the Order, who lived at the turn of the 13th and 14th centuries, who theorized that contemplation can be achieved through imagination, and therefore through art, a principle that will then completely inform the Spiritual Exercises of St. Ignatius. The connection between Ludolfo's Jesuit valence and the total and uninhibited acceptance of the artistic activity of the Carthusians, especially from the end of the 16th century, particularly in Italy, Spain and central Europe, is evident. This acceptance is expressed particularly in the monastery's cenobitic environments, to be decidedly limited to the eremitical ones, of extreme rigor and monumentality.

\section{References}

Bachelard, G. (2006). La poetica dello spazio. Bari: Dedalo.

Calvino, I. (1990). Le città invisibili. 1 th ed. Torino: Einaudi; 1972; De Cunzo M, De Martini V, Giusti M.A.. Certose e certosini in Europa. Napoli: Civita.

De Cunzo, M. (1985). de Martini V. La Certosa di Padula. Firenze: Centro Di.

De Martini, V. (1992). “... E la città è d’oro puro simile a puro cristallo”. In: La Certosa Sotterranea. Napoli: Fausto Fiorentino, p.11-18.

Eco, U. (1980). Il nome della Rosa. 1th ed. Milano: Bompiani.

Hillman, J. (2004). L'anima dei luoghi. Conversazione con Carlo Truppi. 1th ed. Milano: Rizzoli.

Leoncini, G. (1989). Les chartreux, l'art et la spiritualité en Italie. In: Le Blévec D, Girard A. Le Chartreux et l'art XIV-XVIII siècles. Actes du Colloque de Villeneuve-lès-Avignon. Parigi: Du Cerf, p. 231-250. 